\title{
PENGARUH KONSENTRASI BETASIKLODEKSTRIN TERHADAP KELARUTAN IBUPROFEN DAN PENENTUAN PARAMETER TERMODINAMIKA PEMBENTUKAN KOMPLEKS INKLUSI IBUPROFEN- $\beta$-SIKLODEKSTRIN
}

\author{
Fitrianti Darusman*, Tia Aulia Silvianti, Budi Prabowo Soewondo \\ Program Studi Farmasi, Fakultas Matematika dan Ilmu Pengetahuan Alam, Universitas Islam Bandung, Jl. \\ Rangga Gading No. 8, Bandung 40116, Indonesia \\ "email: efit_bien@yahoo.com
}

\begin{abstract}
ABSTRAK
Ibuprofen merupakan turunan asam propionat bersifat analgetik yang mempunyai daya antiinflamasi dan termasuk ke dalam Biopharmaceutic Classification Systems (BCS) kelas II yang mempunyai kelarutan praktis tidak larut dalam air dimana laju pelepasan ibuprofen menjadi penentu absorbsi obat. Salah satu upaya untuk meningkatkan kelarutan ibuprofen yaitu dengan pembentukan kompleks inklusi menggunakan $\beta$-siklodekstrin. $\beta$-siklodekstrin merupakan turunan siklodekstrin yang paling ekonomis dan non toksik saat diberikan secara oral serta ukuran rongganya sesuai untuk banyak obat. Penelitian ini bertujuan untuk melihat pengaruh konsentrasi $\beta$-siklodekstrin terhadap kelarutan ibuprofen serta menentukan parameter termodinamika meliputi entalpi $(\Delta \mathrm{H})$, energi bebas $(\Delta \mathrm{G})$ dan entropi $(\Delta \mathrm{S})$ berdasarkan harga tetapan stabilitas kompleks pada proses pembentukan kompleks inklusi ibuprofen- $\beta$ siklodekstrin. Pembentukan kompleks inklusi antara ibuprofen dengan $\beta$-siklodekstrin dilakukan pada 2 kondisi $\mathrm{pH}$ yaitu dapar sitrat $\mathrm{pH} 5,2$ dan dapar fosfat $\mathrm{pH}$ 7,2 serta 3 kondisi suhu yaitu $32^{\circ} \mathrm{C}, 37^{\circ} \mathrm{C}$ dan $42^{\circ} \mathrm{C}$. Hasil penelitian menunjukkan bahwa semakin tinggi konsentrasi $\beta$-siklodekstrin maka semakin meningkat kemampuan ibuprofen untuk melarut, serta ibuprofen dapat berinteraksi dengan $\beta$-siklodekstrin membentuk kompleks inklusi. Parameter termodinamika pada interaksi yang terjadi di kondisi $\mathrm{pH}$ 5,2 dan 7,2 berlangsung secara eksotermik $(\Delta \mathrm{H}<0)$, proses terjadi secara spontan $(\Delta \mathrm{G}$ negatif) dan terjadi penurunan ketidakteraturan sistem ( $\Delta$ S negatif) yang cenderung lebih tinggi pada kondisi $\mathrm{pH} 5,2$.

Kata kunci: Ibuprofen, $\beta$-siklodekstrin, Kompleks inklusi, Termodinamika.
\end{abstract}

\begin{abstract}
Ibuprofen is an analgesic which considered as propionic acid derivative that has antiinflammatory effect and classified by Biopharmaceous Classification Systems (BCS) as class II drug, this drug practically insoluble in water where the release rate of ibuprofen determines drug's absorption. In order to increase solubility of ibuprofen, the inclusion complex of ibuprofen was made using $\beta$-cyclodextrin. $\beta$-cyclodextrin is the most economical and non-toxic cyclodextrin derivative when given orally and has suitable chamber size for many drugs. This study aims to look at the effect of $\beta$-cyclodextrin concentration on the solubility of ibuprofen and determine the thermodynamic parameters including enthalpy $(\Delta \mathrm{H})$, free energy $(\Delta \mathrm{G})$ and entropy $(\Delta S)$ based on the value of the stability of the complex in the process of forming ibuprofen- $\beta$-cyclodextrin inclusion complex. The complex formation between ibuprofen and $\beta$ cyclodextrin was made in citrate buffer $\mathrm{pH} 5,2$ and phosphate buffer $\mathrm{pH} 7,2$ at $32^{\circ} \mathrm{C}, 37^{\circ} \mathrm{C}$ and $42^{\circ} \mathrm{C}$. The results showed that the higher the concentration of $\beta$-cyclodextrin, the greater the ability of ibuprofen to dissolve, and ibuprofen could interact with $\beta$-cyclodextrin to form an inclusion complex. Thermodynamic parameters in interactions that occur under $\mathrm{pH} 5,2$ and 7,2 occur exothermic $(\Delta \mathrm{H}<0)$, the process occurs spontaneously ( $\Delta \mathrm{G}$ negative) and there is a decrease in system irregularities (negative $\Delta \mathrm{S}$ ) which tends to be higher at $\mathrm{pH} 5,2$.
\end{abstract}

Keywords: Ibuprofen, $\beta$-cyclodextrin, Inclusion complex, Thermodynamics. 


\section{PENDAHULUAN}

Kelarutan merupakan salah satu faktor yang menentukan proses absorpsi, terutama pada sediaan oral. Beberapa obat mempunyai kelarutan yang rendah sehingga perlu adanya upaya untuk meningkatkan kelarutan seperti pada pembentukan kompleks inklusi dengan siklodektrin (Challa R. et al., 2005; Khan, A.N. \& Durakshan, M., 2013). Salah satu obat yang mempunyai kelarutan rendah dan dapat ditingkatkan kelarutannya adalah ibuprofen. Ibuprofen merupakan senyawa turunan asam propionat yang berkhasiat analgetik dan antiinflamasi, diklasifikasikan dalam Biopharmaceutic Classification Systems (BCS) kelas II yang memiliki kelarutan rendah dengan permeabilitas tinggi (Kurdi, M. \& Karam, R., 2015; Sweetman, S.C., 2009).

Siklodekstrin merupakan senyawa oligosakarida siklis berbentuk toroidal (rongga) yang bagian dalamnya bersifat hidrofobik sedangkan bagian luarnya bersifat hidrofilik, mengandung paling sedikit 6 unit D-(+)-glukopiranosa yaitu pada $\alpha$-siklodekstrin, 7 unit $\mathrm{D}$-(+)glukopiranosa pada $\beta$-siklodekstrin dan 8 unit D-(+)-glukopiranosa pada $\gamma$ siklodekstrin, yang berikatan dengan ikatan glukosida $\alpha-1,4$ dengan masing-masing ukuran diameter rongga, berat molekul dan kelarutan dalam air yang berbeda-beda
(Khan, A.N. \& Durakshan, M., 2013; Rowe, R.C., et al, 2009).

Jenis siklodekstrin yang digunakan dalam penelitian ini adalah $\beta$-siklodekstrin karena dilihat dari struktur ibuprofen terdapat gugus aromatik yang memungkinkan untuk berinteraksi dengan $\beta$ siklodekstrin. Selain itu, $\beta$-siklodekstrin digunakan karena merupakan jenis siklodekstrin yang paling ekonomis, non toksik saat diberikan secara oral dan ukuran rongganya sesuai untuk banyak obat (Challa R. et al., 2005; Shewale B.D. et al., 2008).

Kompleks inklusi yang terbentuk antara senyawa obat sebagai guest dengan senyawa siklodekstrin sebagai host didasarkan pada kesesuaian ukuran molekul obat dengan rongga siklodekstrin (faktor geometris) dan hidrofilisitas atau hidrofobisitas molekul obat (faktor polaritas), dimana akan mempengaruhi kemampuan obat untuk berasosiasi dan disosiasi secara berkesinambungan di dalam rongga siklodekstrin. Hal ini dapat ditentukan dari harga tetapan stabilitas kompleks dengan menghitung parameterparameter termodinamika, meliputi entalpi $(\Delta \mathrm{H})$ yang menyatakan proses berjalan secara endotermik atau eksotermik, energi bebas $(\Delta \mathrm{G})$ yang menunjukan kompleks inklusi yang terjadi secara spontan atau tidak spontan, serta entropi $(\Delta \mathrm{S})$ yang menunjukan terjadinya ketidakteraturan 
Pengaruh Konsentrasi Betasiklodekstrin Terhadap Kelarutan Ibuprofen...

sistem dengan tanda positif atau negatif dalam terbentuknya kompleks inklusi (Shimpi, S. et al., 2005; Sinko, P.J, 2011).

Penelitian ini bertujuan untuk melihat pengaruh konsentrasi $\beta$-siklodekstrin terhadap kelarutan ibuprofen agar dapat mengetahui tingkat polaritas ibuprofen dan kecenderungannya membentuk kompleks inklusi dengan $\beta$-siklodekstrin, serta menentukan parameter termodinamika meliputi entalpi $(\Delta H)$, energi bebas $(\Delta G)$ dan entropi $(\Delta \mathrm{S})$ berdasarkan harga tetapan stabilitas kompleks pada proses pembentukan kompleks inklusi ibuprofen- $\beta$ siklodekstrin sehingga mekanisme interaksi keduanya dapat diketahui dan dipahami. Hal ini menjadi penting karena di dalam tubuh obat tidak dapat diserap ketika masih dalam bentuk kompleks dengan $\beta$-siklodekstrin.

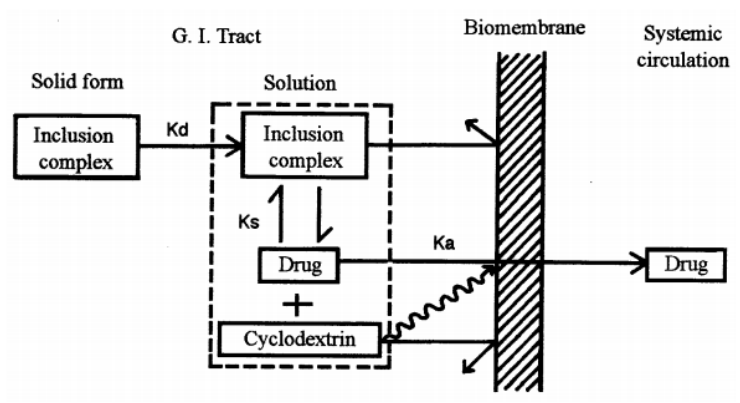

Gambar 1. Mekanisme Absorbsi Obat yang Melibatkan Kompleksasi dengan Siklodekstrin (Uekama, K. \& Otagiri, M., 1987)

\section{METODE PENELITIAN}

\subsection{Alat}

Timbangan analitik (Mettler Toledo, AG204, India), magnetic stirrer-hot plate (Thermo scientific, Denmark), vortex mixer
(Thermo Scientific, Denmark), shaker waterbath (Thermolab, GFL 1092, Germany), pH-meter (Mettler Toledo, India) dan spektrofotometer Ultra Violet (Shimadzu UVmini-1240, Japan).

\subsection{Bahan}

Ibuprofen (IOL Chemical \& Pharmaceutical LTD, India), $\beta$-siklodekstrin (Roquette, Belgium), dinatrium hidrogen fosfat (Merck, USA) dan kalium dihidrogen fosfat (Merck, USA), asam sitrat (Merck, USA), natrium sitrat (Merck, USA), metanol (Merck, USA) dan air suling. Bahan dan reagen yang digunakan adalah grade pro analisis.

\subsection{Prosedur}

Penelitian dimulai dengan pembuatan larutan dapar sitrat $0,01 \mathrm{M} \mathrm{pH} 5,2$ dan larutan dapar fosfat $0,01 \mathrm{M} \quad \mathrm{pH} \quad 7,2$. Kemudian dibuat larutan induk ibuprofen, menentukan panjang gelombang serapan maksimum ibuprofen dan membuat kurva kalibrasi ibuprofen. Setelah itu dilakukan optimasi penentuan waktu kelarutan jenuh ibuprofen yang diambil pada beberapa cuplikan yaitu $0 ; 12 ; 24 ; 36$; dan 48 jam. Selanjutnya, dilakukan uji kelarutan ibuprofen dalam berbagai konsentrasi $\beta$ siklodekstrin $\left(0 ; 2,5 \times 10^{-3} ; 5 \times 10^{-3} ; 7,5 \times 10^{-3}\right.$; dan $\left.10 \times 10^{-3} \mathrm{M}\right)$ yang dilakukan masingmasing dalam larutan dapar sitrat $\mathrm{pH}$ 5,2 dan larutan dapar fosfat $\mathrm{pH} 7,2$ pada suhu $32^{\circ} \mathrm{C}$, $37^{\circ} \mathrm{C}$ dan $42^{\circ} \mathrm{C}$. Sebanyak $5 \mathrm{~mL}$ larutan $\beta$ siklodekstrin dengan kadar dan $\mathrm{pH}$ tertentu 
dimasukkan ke dalam vial $10 \mathrm{~mL}$ dan ditempatkan pada shaker waterbath yang diatur suhunya sesuai suhu percobaan. Kemudian sekitar 50 mg ibuprofen dimasukkan ke dalam vial dan dikocok dengan kecepatan 50 rpm hingga jenuh. Larutan disaring menggunakan kertas Whatman dan ditentukan konsentrasinya menggunakan spektrofotometer ultraviolet

i. Persamaan Henderson-Hasselbach

$$
\mathbf{p H}=\mathbf{p K a}+\log \frac{\left[A^{-}\right]}{[\mathrm{HA}]} \text {. }
$$

(Sinko, 2011: 164)

ii. Tetapan stabilitas kompleks (K)

$$
\mathbf{K}=\frac{\text { Slope }}{\boldsymbol{S}_{\mathrm{0}}(\mathbf{1}-\text { slope })}
$$

Keterangan:

$\mathrm{K} \quad=$ Tetapan stabilitas kompleks

Slope = Kemiringan garis (Konsentrasi betasiklodekstrin )

$\mathrm{S}_{\mathrm{o}} \quad=$ Intercept (Kelarutan ibuprofen $)$

(Shimpi et.al., 2005)

iii. Entalpi $(\Delta \mathbf{H})$

LnK $=-\frac{\Delta H}{R} \cdot \frac{1}{T}+$ konstanta

Keterangan:

$\Delta \mathrm{H}=$ Entalpi $(\mathrm{kal} / \mathrm{mol})$

$\mathrm{K}=$ Tetapan stabilitas kompleks

$\mathrm{R}=$ Tetapan gas $(1,987 \mathrm{kal} / \mathrm{mol} \mathrm{der})$

$\mathrm{T}=$ Suhu $\left({ }^{\circ} \mathrm{K}\right)$

(Sinko, 2011:373)

iv. Energi bebas $(\Delta G)$

$$
\Delta G=-R T L n K \text {. }
$$

Keterangan:

$\Delta \mathrm{G} \quad=$ Energi bebas $(\mathrm{kal} / \mathrm{mol})$

$\mathrm{K}=$ Tetapan stabilitas kompleks

$\mathrm{R} \quad=$ Tetapan gas $(1,987 \mathrm{kal} / \mathrm{mol} \mathrm{der})$

$\mathrm{T}=$ Suhu $\left({ }^{\circ} \mathrm{K}\right)$

(Sinko, 2011:618)

v. Entropi $(\Delta S)$

$\boldsymbol{S}=\frac{\Delta \boldsymbol{H}-\Delta \boldsymbol{G}}{T}$.

Keterangan:

$\Delta \mathrm{S} \quad=$ Entropi $(\mathrm{kal} / \mathrm{mol})$

$\Delta \mathrm{H}=$ Entalpi $(\mathrm{kal} / \mathrm{mol})$

$\Delta \mathrm{G}=$ Energi bebas $(\mathrm{kal} / \mathrm{mol})$

$\mathrm{T}=$ Suhu $\left({ }^{\circ} \mathrm{K}\right)$

(Sinko, 2011:369) pada panjang gelombang $265 \mathrm{~nm}$. Diamati pengaruh konsentrasi $\beta$-siklodekstrin terhadap kelarutan ibuprofen dan dihitung parameter termodinamika meliputi entalpi $(\Delta \mathrm{H})$, energi bebas $(\Delta \mathrm{G})$ dan entropi $(\Delta \mathrm{S})$ berdasarkan tetapan stabilitas kompleks, dengan persamaan-persamaan sebagai berikut: 


\section{HASIL DAN PEMBAHASAN}

\subsection{Pengaruh Konsentrasi $\beta$ - siklodekstrin terhadap Kelarutan Ibuprofen}

Penelitian dilakukan pada dua kondisi $\mathrm{pH}$ yang masing-masing menggunakan larutan dapar yaitu dapar sitrat $\mathrm{pH}$ 5,2 yang sesuai dengan harga pKa 1 ibuprofen (Anonymous, 2017) dan dapar fosfat $\mathrm{pH} 7,2$ yang mewakili kondisi $\mathrm{pH}$ usus (Sweetman, S.C, 2007). Berdasarkan perhitungan persamaan Henderson Hasselbach, pada $\mathrm{pH}$ 5,2 terdapat sekitar 50\% ibuprofen dalam bentuk terionkan, sedangkan pada $\mathrm{pH} 7,2$ jumlah ibuprofen dalam bentuk terionkan sekitar 99,009\%. Kurva kalibrasi ibuprofen dibuat dalam masing-masing larutan dapar tersebut yang diukur menggunakan spektrofotometer ultraviolet pada panjang gelombang serapan maksimum $265 \mathrm{~nm}$, disajikan dalam Gambar 2 dan Gambar 3.

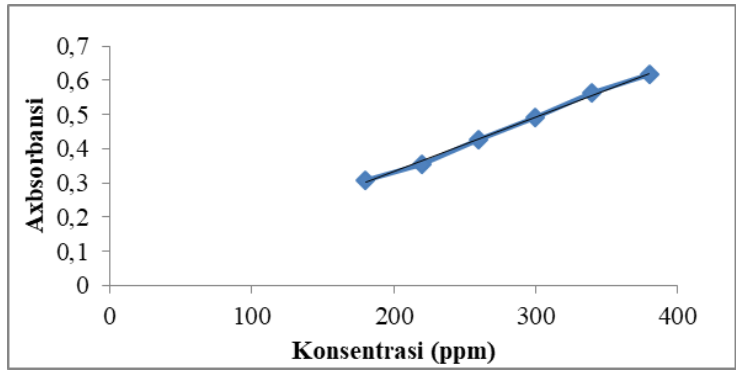

Gambar 2. Kurva Kalibrasi Ibuprofen dalam Larutan Dapar Sitrat pH 5,2

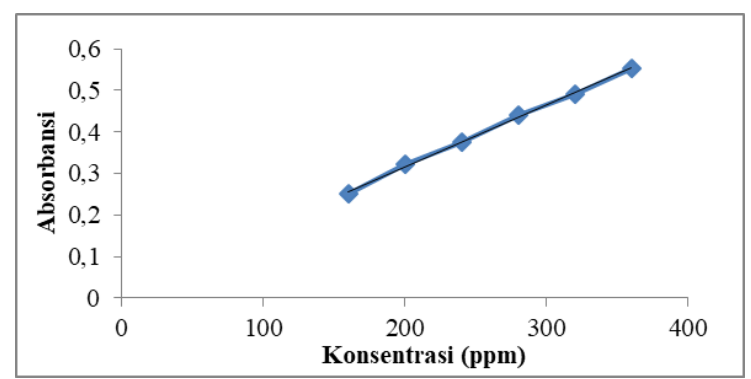

Gambar 3. Kurva Kalibrasi Ibuprofen dalam Larutan Dapar Fosfat 7,2

Dari hasil kurva kalibrasi ibuprofen dalam larutan dapar sitrat $\mathrm{pH}$ 5,2 didapatkan persamaan garis $\mathrm{Y}=0,0016 \mathrm{x}+0,0135$ dengan nilai $r=0,99879$, sedangkan dalam larutan dapar fosfat $\mathrm{pH}$ 7,2 didapatkan persamaan garis $\mathrm{Y}=0,0015 \mathrm{x}+0,0194$ dengan nilai $r=0,99969$.

Penentuan waktu kelarutan jenuh ibuprofen dilakukan untuk menentukan periode kemampuan melarut ibuprofen hingga kondisi jenuhnya yang digunakan pada uji kelarutan ibuprofen dalam berbagai konsentrasi $\beta$-siklodekstrin $\left(0 ; 2,5 \times 10^{-3}\right.$; $\left.5 \times 10^{-3} ; 7,5 \times 10^{-3} ; 10 \times 10^{-3} \mathrm{M}\right)$ yang dilakukan masing-masing dalam larutan dapar sitrat $\mathrm{pH}$ 5,2 dan dapar fosfat $\mathrm{pH} 7,2$ pada suhu $32^{\circ} \mathrm{C}$, $37^{\circ} \mathrm{C}$ dan $42^{\circ} \mathrm{C}$. Dari hasil Tabel 1 dan Tabel 2 menunjukkan bahwa waktu kelarutan jenuh ibuprofen dalam larutan dapar sitrat pH 5,2 yang menghasilkan kadar 2,068 x103 M terjadi pada jam ke-12. Sedangkan waktu kelarutan jenuh ibuprofen dalam larutan dapar fosfat $\mathrm{pH} \quad 7,2$ yang menghasilkan kadar $6,376 \times 10^{-3} \mathrm{M}$ terjadi pada jam ke-24. 
Tabel 1. Hasil Optimasi Penentuan Waktu Kelarutan Jenuh Ibuprofen dalam Larutan Dapar Sitrat pH 5,2

\begin{tabular}{cc}
\hline $\begin{array}{c}\text { Jam } \\
\text { ke- }\end{array}$ & $\begin{array}{c}\text { Kelarutan Ibuprofen }\left(\mathbf{1 0}^{-3}\right. \\
\mathbf{M})\end{array}$ \\
\hline 0 & 1,420 \\
\hline 12 & 2,068 \\
\hline 24 & 1,907 \\
\hline 36 & 1,975 \\
\hline 48 & 1,955 \\
\hline
\end{tabular}

Tabel 2. Hasil Optimasi Penentuan Waktu Kelarutan Jenuh Ibuprofen dalam Larutan Dapar Fosfat pH 7,2

\begin{tabular}{cc}
\hline $\begin{array}{c}\text { Jam } \\
\text { ke- }\end{array}$ & $\begin{array}{c}\text { Kelarutan Ibuprofen } \mathbf{( 1 0}^{-3} \\
\text { M) }\end{array}$ \\
\hline 0 & 6,041 \\
\hline 12 & 6,084 \\
\hline 24 & 6,375 \\
\hline 36 & 6,333 \\
\hline 48 & 5,815 \\
\hline
\end{tabular}

Hasil uji kelarutan ibuprofen dalam larutan dapar sitrat $\mathrm{pH}$ 5,2 dan larutan dapar fosfat $\mathrm{pH}$ 7,2 dengan berbagai konsentrasi $\beta$ siklodekstrin serta variasi suhu dapat dilihat pada Gambar 4 dan Gambar 5.

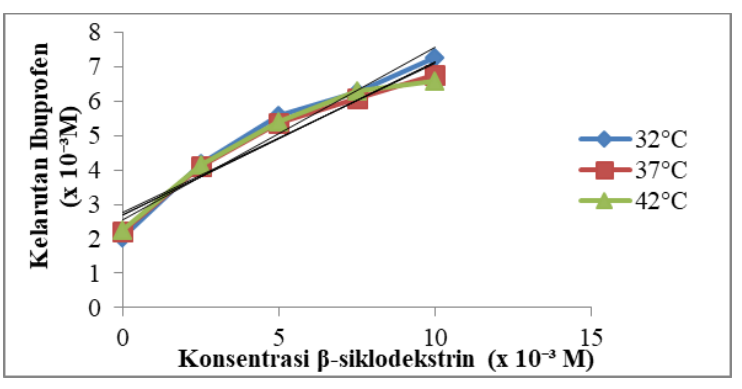

Gambar 4. Kurva Uji Kelarutan Ibuprofen Dalam Larutan Dapar Sitrat pH 5,2 dengan Berbagai Konsentrasi B-Siklodekstrin pada Suhu $32^{\circ} \mathrm{C}, 37^{\circ} \mathrm{C}$, dan $42^{\circ} \mathrm{C}$

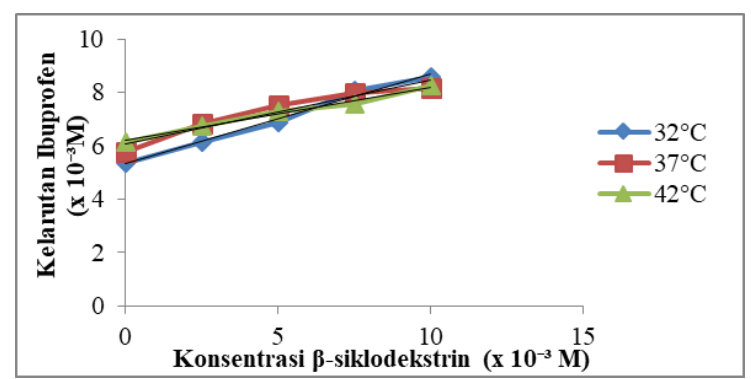

Gambar 5. Kurva Uji Kelarutan Ibuprofen dalam Larutan Dapar Fosfat pH 7,2 dengan Berbagai Konsentrasi $\beta$-siklodekstrin pada Suhu $32^{\circ} \mathrm{C}, 37^{\circ} \mathrm{C}$, dan $42^{\circ} \mathrm{C}$

Dari kurva uji kelarutan diatas, intercept atau titik potong yaitu perpotongan antara kurva dengan sumbu Y menunjukkan konsentrasi ibuprofen bebas dalam larutan sedangkan slope menunjukkan kemampuan $\beta$-siklodekstrin membentuk kompleks dengan molekul ibuprofen. Berdasarkan kurva hubungan kelarutan ibuprofen dengan konsentrasi $\beta$-siklodekstrin diatas pada $\mathrm{pH}$ 5,2 dan $\mathrm{pH} 7,2$ dengan suhu $32^{\circ} \mathrm{C}, 37^{\circ} \mathrm{C}$ dan $42{ }^{\circ} \mathrm{C}$ menunjukkan bahwa persamaan garis mempunyai harga intercept yang semakin meningkat dengan meningkatnya suhu. Hal ini menunjukkan bahwa kelarutan ibuprofen mengikuti proses endotermik yaitu semakin meningkat suhu semakin meningkat pula kelarutan ibuprofen bebas. Harga slope dari kurva pada $\mathrm{pH} 5,2$ dan $\mathrm{pH} 7,2$ di suhu $32^{\circ} \mathrm{C}$, $37^{\circ} \mathrm{C}$ dan $42^{\circ} \mathrm{C}$ menunjukkan hasil yang semakin menurun dengan meningkatnya suhu, hal ini menunjukkan bahwa kenaikan suhu dapat menurunkan kemampuan ibuprofen membentuk kompleks inklusi dengan $\beta$-siklodekstrin. Fenomena ini terjadi 
Pengaruh Konsentrasi Betasiklodekstrin Terhadap Kelarutan Ibuprofen...

karena ibuprofen bebas cenderung mudah larut dengan meningkatnya suhu, sehingga menurunkan kemampuan untuk masuk ke dalam rongga $\beta$-siklodekstrin (Isadiartuti, D.
\& Martohardjo, S. 2007ª). Persamaan regresi yang menyatakan hubungan kelarutan ibuprofen dengan konsentrasi $\beta$ siklodekstrin disajikan dalam Tabel 3.

Tabel 3. Persamaan Regresi Linier Hubungan antara Kelarutan Ibuprofen dengan $\beta$ siklodekstrin

\begin{tabular}{|c|c|c|c|}
\hline \multirow{2}{*}{$\mathbf{p H}$} & \multicolumn{3}{|c|}{ Suhu } \\
\cline { 2 - 4 } & $\mathbf{3 2}^{\circ} \mathbf{C}$ & $\mathbf{3 7}^{\circ} \mathbf{C}$ & $\mathbf{4 2}^{\circ} \mathbf{C}$ \\
\hline 5.2 & $\mathrm{Y}=0,50220 \mathrm{x}+0,0025522$ & $\mathrm{Y}=0,44344 \mathrm{x}+0,0026832$ & $\mathrm{Y}=0,43208 \mathrm{x}+0,0027752$ \\
& $\mathrm{r}=0,97676$ & $\mathrm{r}=0,97410$ & $\mathrm{r}=0,96177$ \\
\hline 7.2 & $\mathrm{Y}=0,33720 \mathrm{x}+0,0053192$ & $\mathrm{Y}=0,23604 \mathrm{x}+0,0060806$ & $\mathrm{Y}=0,20151 \mathrm{x}+0,0061886$ \\
& $\mathrm{r}=0,99361$ & $\mathrm{r}=0,96259$ & $\mathrm{r}=0,99325$ \\
\hline
\end{tabular}

Dapat dilihat pula pengaruh peningkatan konsentrasi $\beta$-siklodekstrin terhadap peningkatan kelarutan ibuprofen sehingga dapat memprediksi terbentuknya kompleks inklusi antara ibuprofen dengan $\beta$ siklodekstrin pada suhu $37^{\circ} \mathrm{C}$. Hasilnya disajikan dalam Gambar 5 dan Tabel 4.

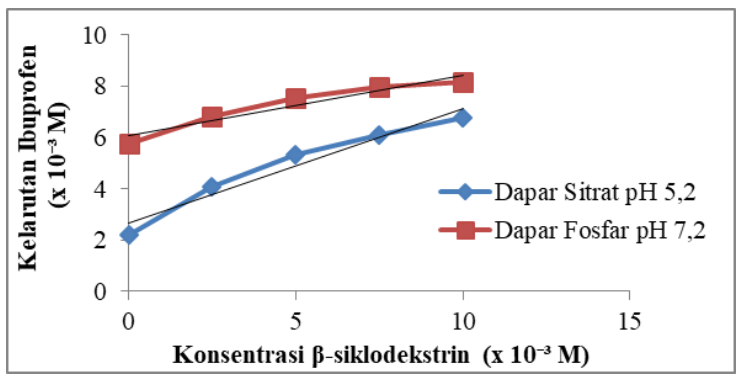

Keterangan :

$\mathrm{pH} 5,2 \rightarrow \mathrm{Y}=0,44344 \mathrm{x}+2,6832 \cdot 10^{-3}(\mathrm{r}=0,97410)$ $\mathrm{pH} 7,2 \rightarrow \mathrm{Y}=0,23604 \mathrm{x}+6,0806.10^{-3}(\mathrm{r}=0,96747)$

Gambar 6. Kurva Hubungan antara Kelarutan Ibuprofen dengan Konsentrasi $\beta$ siklodekstrin pada Suhu $37^{\circ} \mathrm{C}$
Tabel 4. Kelarutan Ibuprofen dalam Larutan Dapar Sitrat pH 5,2 dan Larutan Dapar Fosfat pH 7,2 dengan Berbagai Konsentrasi $\beta$-siklodekstrin pada Suhu $37^{\circ} \mathrm{C}$

\begin{tabular}{ccc}
\hline $\begin{array}{c}\text { Konsentrasi } \boldsymbol{\beta}- \\
\text { Siklodekstrin } \\
\left(\mathbf{x ~ 1 0} \mathbf{1 0}^{-3} \mathbf{M}\right)\end{array}$ & $\begin{array}{c}\text { Kelarutan Ibuprofen } \\
\left(\mathbf{x ~ 1 0} \mathbf{1 0}^{-\mathbf{3}} \mathbf{M}\right)\end{array}$ \\
\cline { 2 - 3 } & $\mathbf{p H ~ 5 , 2}$ & $\mathbf{p H ~ 7 , 2}$ \\
\hline 0 & 2,205 & 5,789 \\
\hline 2,5 & 4,106 & 6,838 \\
\hline 5,0 & 5,346 & 7,528 \\
\hline 7,5 & 6,066 & 7,981 \\
\hline 10,0 & 6,757 & 8,168 \\
\hline
\end{tabular}

Dari Tabel 4 dapat dilihat bahwa semakin tinggi konsentrasi $\beta$-siklodekstrin maka semakin meningkat kemampuan ibuprofen untuk melarut. Harga tetapan stabilitas kompleks di suhu $37^{\circ} \mathrm{C}$ pada $\mathrm{pH}$ 5,2 sebesar 297,012 sedangkan pada $\mathrm{pH}$ 7,2 sebesar 50,815. Dapat dilihat dari hasil tersebut bahwa semakin meningkatnya $\mathrm{pH}$ larutan mengakibatkan penurunan harga tetapan stabilitas kompleks. Hal ini dikarenakan jumlah ibuprofen dalam bentuk 
terionkan pada $\mathrm{pH}$ 7,2 lebih besar dari pada $\mathrm{pH} \quad 5,2$, dimana $\beta$-siklodekstrin dapat membentuk kompleks inklusi apabila berikatan dengan senyawa non polar atau hidrofobik (Isadiartuti, D. \& Martohardjo, S., 2000).

Dari Gambar 6 diatas dapat dilihat bahwa kurva kelarutan ibuprofen dalam $\beta$ siklodekstrin baik pada $\mathrm{pH}$ 5,2 maupun $\mathrm{pH}$ 7,2 membentuk kurva kelarutan tipe $A_{L}$ yaitu terbentuk kompleks yang larut dan tidak terjadi pengendapan dengan semakin meningkatnya konsentrasi $\beta$-siklodekstrin (Isadiartuti, D. \& Martohardjo, S., 2000).

\subsection{Penentuan Parameter Termodinamika Pembentukan Kompleks Inklusi Ibuprofen- $\beta$ - Siklodekstrin}

Penentuan parameter termodinamika $(\Delta \mathrm{H}, \Delta \mathrm{G}$ dan $\Delta \mathrm{S})$ pembentukan kompleks inklusi ibuprofen dengan $\beta$-siklodekstrin diawali dengan menentukan tetapan stabilitas kompleks (K) yang disajikan dalam Tabel 5 dan Tabel 6.

Tabel 5. Harga Tetapan Stabilitas Kompleks $(\mathrm{K})$ dan Parameter Termodinamika $(\Delta \mathrm{H}, \Delta \mathrm{G}$ dan $\Delta \mathrm{S})$ pada $\mathrm{pH} 5,2$

\begin{tabular}{ccccc}
\hline \multirow{2}{*}{$\mathbf{T}\left({ }^{\circ} \mathbf{K}\right)$} & \multirow{K}{*}{$(\mathbf{M})^{-\mathbf{1}}$} & \multicolumn{3}{c}{ Parameter Termodinamika } \\
\cline { 3 - 5 } & & $\mathbf{\Delta H}(\mathbf{k a l} / \mathbf{m o l})$ & $\Delta \mathbf{G ~ ( k a l / m o l )}$ & $\Delta \mathbf{S ~ ( k a l / m o l )}$ \\
\hline 305 & 395,433 & $-7102,982$ & $-3624,089$ & $-11,406$ \\
\hline 310 & 297,012 & $-7102,982$ & $-3507,210$ & $-11,599$ \\
\hline 315 & 274,162 & $-7102,982$ & $-3513,643$ & $-11,395$ \\
\hline
\end{tabular}

Tabel 6. Harga Tetapan Stabilitas Kompleks $(\mathrm{K})$ dan Parameter Termodinamika $(\Delta \mathrm{H}, \Delta \mathrm{G}$ dan $\Delta \mathrm{S})$ pada $\mathrm{pH} 7,2$

\begin{tabular}{ccccc}
\hline \multirow{2}{*}{$\mathbf{T}\left({ }^{\circ} \mathbf{K}\right)$} & \multirow{2}{*}{$(\mathbf{M})^{-\mathbf{1}}$} & \multicolumn{3}{c}{ Parameter Termodinamika } \\
\cline { 3 - 5 } & & $\mathbf{\Delta H}(\mathbf{k a l} / \mathbf{m o l})$ & $\boldsymbol{\Delta G}(\mathbf{k a l} / \mathbf{m o l})$ & $\mathbf{\Delta S}(\mathbf{k a l} / \mathbf{m o l})$ \\
\hline 305 & 95,659 & $-16518,426$ & $-2764,004$ & $-45,097$ \\
\hline 310 & 50,815 & $-16518,426$ & $-2419,653$ & $-45,480$ \\
\hline 315 & 40,137 & $-16518,426$ & $-2321,044$ & $-45,071$ \\
\hline
\end{tabular}

Dari tabel di atas menunjukkan bahwa pada $\mathrm{pH}$ 5,2 dan $\mathrm{pH} 7,2$ dengan adanya kenaikan suhu menyebabkan penurunan harga tetapan stabilitas kompleks. Hal ini menunjukkan bahwa peningkatan suhu menyebabkan kompleks inklusi yang terbentuk semakin tidak stabil sehingga interaksi antara ibuprofen dengan $\beta$-siklodekstrin menjadi lebih mudah lepas (Isadiartuti, D. \& Martohardjo, S. 2007 ${ }^{\text {}}$ ). Dari data harga tetapan stabilitas kompleks (K) dibuat grafik hubungan antara $1 / \mathrm{T}$ terhadap Ln K sesuai Tabel 7. 
Pengaruh Konsentrasi Betasiklodekstrin Terhadap Kelarutan Ibuprofen...

Tabel 7. Persamaan Regresi Linier Hubungan antara 1/T terhadap Ln K

\begin{tabular}{|c|c|}
\hline $\mathrm{pH}$ & Persamaan Regresi Linier \\
\hline 5,2 & $\mathrm{Y}=3574,727 \mathrm{x}-5,770 ; \mathrm{r}=0,956$ \\
\hline 7,2 & $\mathrm{Y}=8313,250 \mathrm{x}-22,753 ; \mathrm{r}=$ \\
0,967
\end{tabular}

Dari data persamaan tersebut dapat dihitung parameter - parameter termodinamika $(\Delta \mathrm{H}, \quad \Delta \mathrm{G}$ dan $\Delta \mathrm{S})$ pembentukan kompleks inklusi ibuprofen dengan $\beta$-siklodekstrin.

Entalpi $(\Delta \mathrm{H})$ merupakan jumlah panas yang diserap atau dilepaskan ketika terjadi proses pelarutan jika satu mol zat terlarut dilarutkan dalam suatu pelarut dalam jumlah besar. Hasil yang diperoleh dari dapar sitrat $\mathrm{pH}$ 5,2 dan dapar fosfat $\mathrm{pH}$ 7,2 menghasilkan harga entalpi dengan tanda negatif yang menunjukkan proses berjalan secara eksotermik. Interaksi yang terjadi antara ibuprofen dan $\beta$-siklodekstrin merupakan interaksi hidrofobik dengan harga $\Delta \mathrm{H}$ pada $\mathrm{pH} 5,2$ sebesar 7102,982 $\mathrm{kal} / \mathrm{mol}$ dan $\mathrm{pH}$ 7,2 sebesar 16814,229 $\mathrm{kal} / \mathrm{mol}$.

Energi bebas $(\Delta \mathrm{G})$ menunjukkan kecenderungan suatu materi untuk berubah. Perubahan energi bebas pada $\mathrm{pH}$ 5,2 dan 7,2 memberikan harga negatif yang menunjukkan bahwa proses pembentukan kompleks berlangsung secara spontan. Hal ini terjadi karena materi cenderung berubah menjadi tidak stabil akibat peningkatan suhu yang menyebabkan terjadinya deformasi struktur kisi kristal sehingga ikatannya menjadi mudah terganggu dan merenggang karena peningkatan suhu akibatnya obat menjadi mudah lepas (Isadiartuti, D. \& Martohardjo, S. 2007 ${ }^{\text {b) }}$.

$$
\text { Entropi }(\Delta \mathrm{S}) \quad \text { menunjukkan }
$$

ketidakteraturan sistem. Hasil yang diperoleh pada $\mathrm{pH}$ 5,2 dan $\mathrm{pH}$ 7,2 didapatkan harga $\Delta \mathrm{S}$ dengan tanda negatif. Hal ini menunjukkan bahwa sistem semakin teratur yang menyebabkan obat sulit memasuki rongga $\beta$-siklodekstrin. Namun jika dilihat harga $\Delta \mathrm{S}$ pada $\mathrm{pH} 5,2$ cenderung mendekati nol (positif) yaitu -11 $\mathrm{kal} / \mathrm{mol}$ daripada $\mathrm{pH}$ 7,2 yaitu $-45 \mathrm{kal} / \mathrm{mol}$. Hal ini mengindikasikan bahwa kemampuan ibuprofen memasuki rongga $\beta$ siklodekstrin untuk membentuk kompleks inklusi lebih besar pada kondisi pH 5,2 karena pada $\mathrm{pH}$ ini jumlah ibuprofen dalam bentuk tak terionkan (non polar) sekitar $50 \%$. Berbeda halnya pada kondisi $\mathrm{pH} 7,2$ jumlah ibuprofen cenderung mengalami ionisasi sempurna (polar) yaitu sekitar 99,099\%. Semakin banyak bentuk tak terionkan pada suatu kondisi $\mathrm{pH}$ tertentu menyebabkan kemampuan melarut menjadi semakin rendah atau hidrofob. Kondisi hidrofob pada suatu molekul guest cenderung mudah memasuki rongga $\beta$ siklodekstrin sehingga menyebabkan ketidaktidakteraturan sistem air yang mengelilingi rongga $\beta$-siklodekstrin karena perbedaan kepolaran. Akibatnya air 
tersebut keluar dari rongga, kemudian kondisi ini dengan cepat digantikan oleh guest yang bersifat nonpolar (Isadiartuti, D. \& Martohardjo, S. 2007 ${ }^{\mathrm{b}}$ ).

\section{KESIMPULAN}

Berdasarkan hasil penelitian ini, dapat disimpulkan bahwa semakin tinggi konsentrasi $\beta$-siklodekstrin maka semakin meningkat kemampuan ibuprofen untuk melarut, serta ibuprofen dapat berinteraksi dengan $\quad \beta$-siklodekstrin membentuk kompleks inklusi. Parameter termodinamika pada interaksi yang terjadi di kondisi $\mathrm{pH}$ 5,2 dan 7,2 berlangsung secara eksotermik $(\Delta \mathrm{H}<0)$, proses terjadi secara spontan $(\Delta \mathrm{G}$ negatif) dan terjadi penurunan ketidakteraturan sistem $(\Delta S$ negatif) yang cenderung lebih tinggi pada kondisi $\mathrm{pH}$ 5,2.

\section{UCAPAN TERIMA KASIH}

Penulis mengucapkan terima kasih kepada PT Mega Setia Jakarta atas sumbangan bahan baku ibuprofen serta kepada Program Studi Farmasi Universitas Islam Bandung atas fasilitas laboratorium yang digunakan dalam penelitian ini.

\section{DAFTAR PUSTAKA}

Anonymous. (2017). The United States Pharmacopeia, Edition $41^{\text {th }}$ NF 36. United States of America, (1), 2109.

Challa R, Ahuja A, Ali J, \& Khar RK. (2005). Cyclodextrins in Drug Delivery : An Updated Review. AAPS Pharmaceutical Science Technology, 6(2).
Isadiartuti D, \& Martohardjo S. (2007) ${ }^{\mathrm{a}}$. Pengaruh senyawa hidroksipropil- $\beta$ siklodekstrin terhadap kelarutan fenobarbital. Majalah Farmasi Indonesia, 11(4), 205-208.

Isadiartuti D, \& Martohardjo S. (2007) ${ }^{\mathrm{b}}$. Termodinamika pembentukan kompleks inklusi fenobarbitalhidroksipropil- $\beta$-siklodekstrin.

Majalah Farmasi Indonesia, 18(22), 57-62.

Isadiartuti D, \& Martohardjo S. (2000). Pengaruh senyawa hidroksipropil- $\beta$ siklodekstrin terhadap kelarutan Fenobarbital. Majalah Farmasi Indonesia. 11(4), 205-208.

Khan AN, \& Durakshan M. (2013). Cyclodextrin: An Overview. IJBIO. 02(06), 858-865.

Kurdi M, \& Karam R. (2015). Biowaivers : Criteria and Requirements, Ministry Of Public Health (MOPH), 1-8.

Rowe RC, Sheskey PJ, \& Quinn ME. (2009). Handbook of Pharmaceutical Excipients, $6^{\text {th }}$ Edition, USA, Phamaceutical Press.

Sinko PJ. (2011). Farmasi Fisika \& Ilmu Farmasetika Martin Edisi 5, alih bahasa, Joshita Djajadisastra, Amalia H. Hadinata, EGC, Jakarta.

Shewale BD, Fursule RA, \& Sapkal NP. (2008). Effect of $\mathrm{pH}$ and Hydoxypropyl- $\beta$-Cyclodextrin on Solubility and Stability of Glicazide. International Journal and Health Research, 1(2), 95-99.

Shimpi S, Chauhan B, \& Shimpi P. (2005). Cyclodextrin Application in Different Routes of Drug Administration, Acta Pharm, 55, 139-155.

Sweetman SC. (2009). Martindale : The Complete Drug Reference, $36^{\text {th }}$ Edition, London, Phamaceutical Press , 44-47.

Uekama, K. \& Otagiri, M., (1987). Cyclodextrins in drug carrier systems. CRC Crit. Rev. Ther. Drug Carrier Syst. 3, 1-40. 